IJ§ER

ISSN: 2149-5939
International Journal of Social Sciences and Education Research

Online, http://dergipark.gov.tr/ijsser

Volume: 1(2), 2015

\title{
Illetişim Fakültesi öğrencilerinin gazetelere güven düzeyleri üzerine bir araştırma
}

\section{A study of the reliability levels of the Faculty of Communication students on news- papers}

\author{
Erol İlhan ${ }^{1} \quad$ Alper Çetintaş²
}

Received Date: $01 / 02$ / 2015

Accepted Date: $01 / 04$ / 2015

$\ddot{O} z$

“İletişim Fakültesi Öğrencilerinin Gazetelere Güven Düzeyleri Üzerine Bir Araştırma” başlıklı çalışmada, Ankara'da eğitim-öğretim faaliyetlerini sürdüren üniversitelerin iletişim fakültesi öğrencilerinin gazetelerde verilen haberlerin güvenirliliği ile ilgili tutumları belirlenmeye çalışılmıştır. Keşfedici ve betimleyici bir çalışma olan bu makale Gazi, Ankara ve Başkent Üniversiteleri İletişim Fakültelerinde okuyan birinci ve dördüncü sınıf öğrencilerini kapsamaktadır. Çalışmada öncelikle literatür taraması yapılmış ve tesadüfi örnekleme yoluyla belirlenen 236 öğrencinin, görüşlerini ölçebilmek amacıyla anket uygulanmıştır. Anket çalışmasından elde edilen veriler ışığında öğrencilerin büyük çoğunluğunun gazetelerde verilen haberlere güvenmediği ortaya çıkmıştır. Yine elde edilen veriler neticesinde ankette sorulan soruların çoğunluğuna dördüncü sınıf öğrencilerinin birinci sınıf öğrencilerine oranla daha olumsuz cevaplar verdiği saptanmıştır.

Anahtar sözcükler: Medya, haber, gazete, iletişim fakültesi, güven düzeyi

\begin{abstract}
"A study of the Reliability Levels of the Faculty of Communication Students On Newspaper" aims to figure out the Faculty of Communication students' attitudes at the universities in Ankara towards the reliability of the news reported in newspapers. Exploratory and participants of this descriptive study includes the first and fourth grade students in the Faculty of Communication in Gazi, Ankara and Başkent Universities. Literature review was used as a method and a survey was conducted to evaluate the ideas of the 236 students. In the spotlight of the data acquired in this survey study, it is revealed that most of the participants do not rely on the news in media. In addition, it was seen that fourth-grade students in the study had more negative answers compared to first grade students.
\end{abstract}

Keywords: Media, news, newspapers, faculty of communication, reliability level

\section{Giriş}

Gazeteler ortaya çıktıkları ilk dönemden itibaren yöneten ve yönetilenler açısından büyük önem taşımıştır. Haber mektupları şeklinde ortaya çıkan ilk gazeteler hızlı bir gelişme süreci geçirerek, demokratik toplumlarda dördüncü güç olma özelliği kazanmıştır Bir kitle iletişim aracı olan gazetenin elde ettiği bu güç, sahiplik yapısı, yönetim şekli ve bu araçların kullanım amaçlarına kadar birçok konuda değişiklik yaşanmasına neden olmuştur. Kitlelerin gözü ve kulağı durumunda olan basın güç ve sahiplik yapısının değişmesiyle birlikte asli görevleri arasında gösterilen kamuoyu oluşturma ve kamuoyunu doğru bilgilendirme görevlerinden giderek uzaklaşmaya başlamıştır.

\footnotetext{
${ }^{1}$ Asst. prof. Dr., Gazi University, Faculty of Communication, ANKARA/TURKEY, erol@gazi.edu.tr

${ }^{2}$ Gazi University, Faculty of Fine Arts, ANKARA/TURKEY, alpercetintas23@hotmail.com
} 
İlhan, E., Çetintaş, A. (2015). A study of the reliability levels of the Faculty of Communication students on newspapers. International Journal of Social Sciences and Education Research, 1 (2), 560-571.

Medyanın demokratik toplumlarda kendisine yüklenen işlevleri yerine getirebilmesi, büyük oranda okurlarıyla kurduğu ilişkiye bağlıdır. Günümüzde ise basın kuruluşlarının kâr olgusunu ön plana çıkaran bir anlayışla faaliyetlerini yürüttüğü görülmektedir. Yakın zamanda yapılan birçok araştırmada, basın kuruluşlarına duyulan güvenin sarsıldığı görülmektedir. Bu bağlamda çalışmaya referans olabilecek bazı araştırma bulguları şöyledir: 1998 yılında TESEV tarafindan hazırlanan ve 2705 kişi üzerinde yürütülen bir araştırmada basının yüzde 50 güven oranına sahip olduğu saptanmıştır (http://www.akademycafe.com).

2000 yılında Taylor Nelson-Sofres-Piar tarafindan 2007 kişi üzerinde yapılan araştırmada Türkiye'de halkın medyaya duyduğu güveninin sadece yüzde 28,5 olduğu saptanmıştır (http://www.akademycafe.com). Demokrasinin sağlıklı bir biçimde işleyebilmesi, gazetelerin varlıklarını sürdürebilmeleri güvenilir haber vermelerine ve bunun sonucunda okuyucularının güvenini kazanabilmelerine bağlıdır. Bu noktada nesnellik ilkesini yeterince sağlayamayan gazetelere içinde bulunduğumuz bu dönemde duyulan güven gittikçe azalmıştır.

$\mathrm{Bu}$ çalışmada, medya-okur ilişkileri çerçevesinde iletişim fakültesi öğrencilerinin gazetelerde verilen haberleri nasıl algıladıkları, verilen haberlere ne derece güven duydukları ve bu haberlere nasıl tepki verdikleri belirlenmeye çalışılmıştır. Bu değerlendirme, Türkiye'de medya-okur ilişkilerinin niteliğinin anlaşılması ve iletişim fakültelerinde okuyan öğrencilerin aldıkları eğitim sonucu gazetelerde verilen haberlere karşı tutumlarını ortaya koyması açısından önemlidir.

\section{Kavramsal çerçeve}

Haber, medya içerik türleri arasında bireysel, kültürel, siyasal, ekonomik işlev ve etkileri bakımından önde gelen bir konumda bulunmaktadır. Toplumsal yapıdaki işlevleri ve medya içerikleri içerisindeki ayrıcalıklı konumu düşünüldüğünde haber, tanımı üzerinde olduğu kadar yapısal ve işlevsel özellikleri açısından da üzerinde durulması gereken bir kavramdır. Çağdaş kitle iletişim olgusunun ortaya çıkmasıyla birlikte haber; toplumun durumunun, gelişimin çizgisi ve yönünün, sorunları ve umutlarının kaydedildiği bir araca dönüşmüştür (Çebi, 2002: 13-21).

Haber çalışmaları iki farklı kuramsal ve yöntem bilimsel yaklaşım ekseninde gelişmiştir. Bunlardan ilki, ana damar liberal-çoğulcu yaklaşım ve yöntembilim anlayışıdır. Haber araştırmalarının ilk dönemine damgasını vuran liberal-çoğulcu yaklaşımın sorunsallaştırdığı temel konu, öncelikle haber seçimi olmuştur. Anket ve içerik çözümlemesi gibi nicel veri toplama yöntemlerini kullanan pozitivist eğilim, genelde bireysel, mesleki ve örgütsel etmenlerin haber üretimi sürecindeki rolü üzerinde yoğunlaşmıştır (Çebi, 2002: 56-57)

Liberal çoğulcu yaklaşım medyayı toplumsal olayları ve gerçekleri yansıtan bir ayna olarak tanımladığından tarafsız bir haberi de doğru ile özdeş sayar. Bu yaklaşımda nesnellik, tarafsızlık ve dengelilik gibi değerler kutsal birer kavram haline gelmektedir (Tılıç, 1998: 164). Liberalçoğulcu yaklaşımın habere ilişkin hareket noktasını, haber öyküsüne dönüştürülecek bir olayın seçilmesinde ve haber içeriğinin belirlenmesinde geçerli olan haber değeri ölçütleri ile gazeteciliğin profesyonellik kodları oluşturmaktadır. Temel haber değeri ölçütlerine uygun olaylar, doğru, nesnel ve yansız biçimde haber öyküsüne dönüştürülerek medya alıcılarına sunulur (Çebi, 2002: 21).

17. yüzyılda ortaya çıkmaya başlayan ve günümüze değin gelişimini sürdüren basın kuruluşları liberal medya prensiplerin geliştirilmesinde önemli bir rol üstlenmiştir. Gazeteler devletin müdahale ve sınırlandırma girişimleriyle mücadele ederken, basın özgürlüğünün modern anlamda 
İlhan, E., Çetintaş, A. (2015). İletişim Fakültesi öğrencilerinin gazetelere güven düzeyleri üzerine bir araştırma. International Journal of Social Sciences and Education Research, 1 (2), 560-571.

ifadesi için, objektif gazetecilik teorisi ortaya konulmuştur(Işık, 2002: 20). Bu kapsamda, haber değeri kriterlerine bağlı kalarak düzenlenen haberlerin yansız olarak sunulması ve etik kurallara uyulması gerekmektedir. Böylelikle liberal basın anlayışı çerçevesinde haber açısından üç boyut öne çıkmaktadır. Bunlar objektif habercilik ideali, haber değerliliği ölçütleri ve gazetecilik etik ilkeleridir (Özer ve Üçer, 2012: 120).

Liberal-çoğulcu yaklaşıma göre haberler; gerçekliği tamamen nesnel, dengeli ve tamamen yansız bir şekilde yansıtabilir. Nesnellik olguların yorumlardan ayrılabildiğini gazetecilerin öznel duygu, düşünce ve değer yargılarından sıyrılarak dış dünyaya ilişkin olaylara mesafeli durabileceği varsayımına dayanır. Yansızlık, gazetecilerin değer ve tutumlarının, siyasal ve ideolojik eğilimlerinin, medya öğütlerinin yayın politikasının haber seçimi, oluşumu ve sunumuna yansımaması ve habere konu olan tarafların haber metninde adil ve dengeli biçimde temsil edilmesi gereğine vurgu yapmaktadır. Öte yandan tarafsızlık haberde birbirleri ile çatışan düşünce ve bakış açılarına nicel ve nitel açıdan dengeli biçimde yer verilmesini de öngörmektedir (Çebi, 2002: 128). Nesnellik kavramına göre, haberde kişisel olmayan veriler konuşur, hiçbir değer yargısı yoktur. Haber/haberci siyasal ve ideolojik bakımdan yansızdır. Yansızlık kavramı ise haber hizmetlerinde çalışanların belirli bir konuda kendi duyguları, çıkarları ve değer yargılarından bağımsız olarak tarafların görüşlerini vermelerini anlatır. Yansızlık, nesnelliğin tamamlayıcısıdır (Erdoğan ve Korkmaz, 1990: 57-58).

Gerçekliğin kitle iletişim araçlarında aynen yansıtılıp-yansıtılmadığı defalarca sorgulandı. Bu sorgulamanın nedenlerinden ilki, kitle iletişim araçlarının gündem oluşturma sırasında kaçınılmaz olarak bir seçme sürecine tabi olmalarıdır. Seçme işlemi öncelikle aktarılacak olaylar arasından yapılır. Daha sonra da aktarılacak olayların hangi ögelerinin içerikte korunması gerektiğine karar verilir. Sonuç olarak iletişim sürecinin alıcı tarafında bulunanların zihninde oluşan dünya, birçok olay ve görüntü arasından seçilmiş olayların yeniden kurgusundan başka bir şey değildir (Poyraz, 2002: 11).

Liberal-çoğulcu tasarımların odağında bulunan nesnelliğe yapılan itirazlar iki temele dayanmaktadır. Bunlardan ilki, mutlak anlamda nesnelliğin mümkün olmadığıdır. İkinci nokta ise, nesnelliğ in istenir bir şey olmadığıdır. Nesnelliğin mümkün olmayacağı argümanı, çeşitli nedenlere dayanmaktadır. Bunlardan birincisi, haber seçimi sürecinin kaçınılmaz biçimde öznel değer, tutum ve yargılara açık olduğudur. Gazeteci bu etmelerin haber üzerindeki etkisinin farkında olmayabilir. İkincisi bütün olayların ve bu olaylarla ilgili haberlerin yerleştirildiği geniş ve anlamlı referans çerçeveleridir. Üçüncüsü, örtük de olsa toplum ve onun değerleri hakkında öznel değerleri ve varsayımları yansıtan ihmal ve suskunluklardır. En yaygın olan neden dördüncü neden ise, açıkça bilindiği gibi sürekli olarak haberlerin çok çeşitli ve güçlü içsel ve dışsal baskılar altında üretilmesidir. Bu baskılar, neredeyse gazeteciliğin gerçeği aktarma idealini engelleyerek bu idealden sapmasına yol açmaktadır (Çebi, 2002: 130).

Özer'e (2010: 110-112) göre, 21. yüzyıl haber tüketicileri objektif yayıncılık idealinin, sadece bir ideal olduğunun ve gazetecilik pratiğinde tümüyle başarılamayacağının farkındadır. Haber medyası toplumsal ve siyasal olayları temsil ederken bu olayları öncesinde var olmayan biçimde yapılaştırarak sunmaktadır. Bu düşüncedeki araştırmacılar, haber medyasının bir ayna işlevi gördüğüne ilişkin 'medya toplumsal gerçekleri yansıtır' yolundaki metaforu reddetmektedir. Bazı eleştirmenler, gazeteciliğin olaylara ilişkin içsel anlamı ya da olanı doğrudan aktaramayacağını belirtmişlerdir. 
İlhan, E., Çetintaş, A. (2015). A study of the reliability levels of the Faculty of Communication students on newspapers. International Journal of Social Sciences and Education Research, 1 (2), 560-571.

Objektif habercilik idealinin gerçekleşmesi açısından gerekenler dört başlık altında toplanabilir. Bu ifade aynı zamanda, objektifliğin ihlal edildiği alanların da dört başlıkta toplanabileceğini içermektedir. Söz konusu unsurları önyargı grubu, çarpıtma, doğruluk ve olay/yorum farkı başlıklarında sunmak mümkündür (Özer, 2012: 235).

Özetle, liberal demokratik rejimlerde medyanın görevi, doğru, objektif ve tarafsız politik bilgileri ve haberleri, idarenin icraatlarını ve vatandaşların talep, görüş ve beklentilerini karşılıklı olarak eksiksiz ileterek, çeşitli görüşleri savunan politik kadroların kendilerine çeki düzen vermelerine ve seçmenlerin, kendilerini temsil edecek kişileri, bu bilgilendirme sonucunda akılcı bir şekilde seçebilmelerine olanak sağlamaktadır (Oktay, 2002: 28).

\section{Araştırma yöntemi}

Araştırmanın evrenini Ankara'daki; Gazi Üniversitesi, Ankara Üniversitesi ve Başkent Üniversitesi iletişim fakültelerinde okuyan birinci ve dördüncü sınıf öğrencileri oluşturmuştur. $\mathrm{Bu}$ fakültelerdeki öğrenciler arasından tesadüfi örneklem yöntemine göre seçim yapılmış ve araştırmanın örneklemi meydana getirilmiştir. Keşfedici ve betimleyici bu çalışmada öğrencilerinin görüşlerini yansıtmak için anket yöntemi kullanılmıştır. Kullanılan anket formu, alanında uzman öğretim üyeleri gözetiminde hazırlanmıştır. İki kısımdan oluşan anketin ilk kısmında katılımcıların demografik özellikleri ve günlük haberleri en çok hangi kanaldan aldıkları, daha çok ne tür haberleri takip ettiklerini öğrenmeye yönelik sorular yöneltilmiştir.

Anketin ikinci kısmında ise katılımcıların gazetelere güven düzeylerini saptamaya yönelik 5'li likert tipi ölçüm aracı kullanılmıştır. Verilerin yorumlanabilmesi için ise SPSS (ver: 16.00) programı kullanılmıştır. Ankette yer alan soruların birbirleriyle olan tutarlığını ölçmek için yapılan güvenilirlik analizinde Cronbach's Alpha katsayısı 0.852 olarak ölçülmüştür. Çalışmanın veri sayısını indirgemek ve anket geçerliliğini test etmek amacıyla faktör analizi yapılmıştır. Faktör analizi değişkenler arasındaki temel boyutları veya faktörleri tespit etmeye çalışan, değişkenler arasında herhangi bir bağımlı veya bağımsız ayrımı yapmaksızın tüm değişkenler arasındaki ilişkileri dikkate alan bir analiz tekniğidir (Altunışık, 2002).

\section{Bulgular}

Araştırmaya tesadüfi olarak 118 kadın ve 118 erkek olmak üzere toplam 236 öğrenci katılmıştır. Dolayısıyla ankete yanıt veren kadın ve erkeklerin oranları \% 50 olmuştur. Ankete katılan öğrencilerin \% 9,7'si 20 yaş altında, \% 85,2'si 20-25 yaş aralığında, \% 3,8'i 26-31 yaş aralığında, $\% 1,3$ 'ü ise 32 yaşın üstündedir. Ankara bağlamında yapılan anket çalışmasında katılımcıların 90’’nı (\% 38,1) Gazi Üniversitesi öğrencileri, 74'ünü $(31,4)$ Ankara Üniversitesi öğrencileri, 72'sini $(30,5)$ Başkent Üniversitesi öğrencileri oluşturmaktadır.

Deneklerin \% 37,7'sini (89) Gazetecilik Bölümü öğrencileri, \% 32,2'sini (76) Halkla İlişkiler ve Tanıtım Bölümü öğrencileri, \% 24,6'sını (58) ise Radyo Televizyon ve Sinema Bölümü öğrencileri oluşturmaktadır. Araştırmada yer alan 236 öğrencinin 124'ünü (\% 52,5) 1. sınıf öğrencileri, 112'sini ise (\% 47,5) 4. sınıf öğrencileri oluşturmaktadır. Öğrencilerin üniversitelere göre dağılımına baktığımız zaman, ankette yer alan 124 birinci sınıf öğrencisinin 48'inin (\% 20,3) Ankara Üniversitesi'nden, 39'unun (\% 16,5) Başkent Üniversitesi'nden, 37'sinin (\% 15,7) ise Gazi Üniversitesi'nden olduğu görülmektedir. Ankette yer alan 112 dördüncü sınıf öğrencisinin ise 53'ünün (\% 22,5) Gazi Üniversitesi öğrencisi olduğu, 33'ünün (\% 14) Başkent Üniversitesi öğrencisi ve 26'sının (\% 11) ise Ankara Üniversitesi öğrencisi olduğu görülmektedir. Tablo 1'de 
İlhan, E., Çetintaş, A. (2015). İletişim Fakültesi öğrencilerinin gazetelere güven düzeyleri üzerine bir araştırma. International Journal of Social Sciences and Education Research, 1 (2), 560-571.

öğrencilerin günlük haberleri en çok hangi kanaldan takip ettiğine ilişkin yüzdelik dağılımları yer almaktadir.

Tablo 1. Günlük haberlerin hangi kanaldan takip edildiğine ilişkin dă̆ılım

\begin{tabular}{|l|l|l|}
\hline İletişim aracı & Öğrenci sayısı & Oran (\%) \\
\hline Gazete & 26 & 11 \\
\hline Televizyon & 69 & 29,2 \\
\hline İnternet & 134 & 56,4 \\
\hline Radyo & 7 & 3 \\
\hline Toplam & 236 & 100 \\
\hline
\end{tabular}

Tablo 1'de öğrencilerin haberleri ağılıklı olarak internet üzerinden takip ettiği ortaya çıkmaktadır. Ankete katılan öğrencilerin \% 56,4'ü (134) günlük haberleri internet üzerinden takip ettiklerini belirtirken, \% 29,2'si (69) televizyondan, \% 11'i (26) gazeteden, \% 3'ü (7) ise radyodan takip ettiğini belirtmiştir.

Tablo 2. Ne tür haberlerin takip edildiğine ilişkin dağ 11 ım

\begin{tabular}{|l|l|l|}
\hline Haber türü & Öğrenci sayısı & Oran (\%) \\
\hline Politika-Siyaset & 83 & 35,2 \\
\hline Gündem & 66 & 28 \\
\hline Spor & 31 & 13,1 \\
\hline Magazin & 15 & 6,4 \\
\hline Diğer & 41 & 17,3 \\
\hline Toplam & 236 & 100 \\
\hline
\end{tabular}

Araştırmaya katılan öğrencilerin \% 35,2'si (83) en fazla politika-siyaset haberlerini takip ettiklerini, \% 28'i (66) ise gündemi, \% 13,1'i (31) spor haberlerini, \% 6,4’ü ise magazin haberlerini en fazla takip ettiğini belirtmiştir.

Tablo 3. Hangi kitle iletişim aracının haber almada daha güvenilir olduğuna ilişkin dağılım

\begin{tabular}{|l|l|l|}
\hline Haber kanalı & Öğrenci sayısı & Oran (\%) \\
\hline Televizyon & 83 & 34,7 \\
\hline Gazete & 74 & 30,9 \\
\hline İnternet & 46 & 19,5 \\
\hline Radyo & 13 & 5,5 \\
\hline Diğer & 20 & 8,5 \\
\hline Toplam & 236 & 100 \\
\hline
\end{tabular}

Katılımcıların \% 34,7 (83) haber almada en güvenilir kitle iletişim aracının televizyon olduğunu, \% 30,9'u (74) gazetenin, \% 19,5'i (46) internetin, \% 5,5'i (13) ise radyonun daha güvenilir olduğunu ifade etmiştir.

Tablo 4. "Gazete haberciliği güvenilirdir"

\begin{tabular}{|l|c|c|}
\hline & Öğrenci sayısı & Oran (\%) \\
\hline Hiç Katılmıyorum & 25 & 10,2 \\
\hline Kısmen Katılmıyorum & 58 & 24,2 \\
\hline Kararsızım & 48 & 19,9 \\
\hline Katılıyorum & 71 & 29,2 \\
\hline Tamamen Katılıyorum & 34 & 14 \\
\hline Toplam & $\mathbf{2 3 6}$ & $\mathbf{1 0 0}$ \\
\hline
\end{tabular}


İlhan, E., Çetintaş, A. (2015). A study of the reliability levels of the Faculty of Communication students on newspapers. International Journal of Social Sciences and Education Research, 1 (2), 560-571.

Katılımcıların \% 34,4'lük (83) kısmı gazete haberciliğinin güvenilir olduğuna ya hiç katılmadığını ya da kısmen katılmadığını belirtmiştir. Bu konuda kararsız olduğunu belirtenlerin oranı ise \% 19,9'luk (48) kısmı oluşturmaktadır. Gazete haberciliğinin güvenilir olduğuna katılanların oranı ise \% 43,2 (105) olarak belirlenmiştir.

Tablo 5. "Gazete haberciliği güvenilirdir" sınıflara ilişkin dağılım

\begin{tabular}{|l|c|c|}
\hline & 1. Sınıf & 4. Sınıf \\
\hline Hiç Katılmıyorum & $7(5,7)$ & $18(15,7)$ \\
\hline Kısmen Katılmıyorum & $32(26,2)$ & $26(23,1)$ \\
\hline Kararsızım & $19(14,8)$ & $30(26,9)$ \\
\hline Katılıyorum & $48(38,5)$ & $22(20,4)$ \\
\hline Tamamen Katıliyorum & $19(14,8)$ & $15(13,9)$ \\
\hline Toplam (\%) & $\mathbf{1 2 5}(\mathbf{1 0 0})$ & $\mathbf{1 1 1 ( 1 0 0 )}$ \\
\hline
\end{tabular}

Araştırmaya katılan 1. Sınıf öğrencilerinin \% 31,9’u (39) gazete haberciliğini güvenli bulmazken \% 53,3'ü (67) gazete haberliğini güvenli bulduğunu ifade etmiştir. 4. Sınıf öğrencilerinin ise \% 38,9'u (44) gazete haberciliğinin güvensiz olduğunu ifade etmiş, \% 34,3’ü (37) ise gazete haberciliğini güvenli bulmuştur.

Tablo 6. "Gazeteler doğruluğu kanıtlanmış bilgiler sunmaktadır"

\begin{tabular}{|l|c|c|}
\hline & Öğrenci sayısı & Oran (\%) \\
\hline Hiç Katılmıorum & 28 & 11,9 \\
\hline Kısmen Katılmıyorum & 49 & 20,3 \\
\hline Kararsızım & 58 & 24,2 \\
\hline Katılıyorum & 78 & 32,6 \\
\hline Tamamen Katılıyorum & 23 & 9,7 \\
\hline Toplam & $\mathbf{2 3 6}$ & $\mathbf{1 0 0}$ \\
\hline
\end{tabular}

Katılımcıların \% 32,2'si (77) kısmı gazetelerin doğruluğu kanıtlanmış bilgiler sunduğuna ya hiç katılmadığını ya da kısmen katılmadığını belirtmiştir. Bu konuda kararsız olduğunu belirtenlerin oranı ise \% 24,2'lik (58) kısmı oluşturmaktadır. Gazetelerin doğruluğu kanıtlanmış bilgiler sunduğuna katılanların oranı ise \% 42,3 (101) olarak belirlenmiştir.

Tablo 7. Gazeteler doğruluğu kanıtlanmış bilgiler sunmaktadır (sınıflar)

\begin{tabular}{|l|c|c|}
\hline & 1. Sınıf & 4. Sınıf \\
\hline Hiç Katılmıorum & $12(9,8)$ & $16(14,4)$ \\
\hline Kısmen Katılmıyorum & $22(18,0)$ & $26(23,4)$ \\
\hline Kararsızım & $29(23,0)$ & $30(26,1)$ \\
\hline Katıliyorum & $48(38,5)$ & $30(27,0)$ \\
\hline Tamamen Katıliyorum & $13(10,7)$ & $10(9,0)$ \\
\hline Toplam (\%) & $\mathbf{1 2 4}(\mathbf{1 0 0})$ & $\mathbf{1 1 2}(\mathbf{1 0 0})$ \\
\hline
\end{tabular}

Araştırmaya katılan 1. Sınıf öğrencilerinin \% 27,8’i (34) gazetelerin doğruluğu kanıtlanmış bilgiler sunmadığını dile getirirken \% 49,2'si (61) gazetelerin doğruluğunu kanıtlanmış bilgiler sunduğunu kaydetmiştir. 4. Sınıf öğrencilerinin ise \% 37,8'i (42) gazetelerin doğruluğu kanıtlanmış bilgiler sunmadığını ifade etmiş, \% 36'sı (40) ise gazetelerin doğruluğu kanıtlanmış bilgiler sunduğunu belirtmiştir. 
İlhan, E., Çetintaş, A. (2015). İletişim Fakültesi öğrencilerinin gazetelere güven düzeyleri üzerine bir araştırma. International Journal of Social Sciences and Education Research, 1 (2), 560-571.

Tablo 8. Gazeteler haberde farklı görüşlere yer vermemektedir

\begin{tabular}{|l|c|c|}
\hline & Öğrenci Sayısı & Oran (\%) \\
\hline Hiç Katılmıyorum & 12 & 5,1 \\
\hline Kısmen Katılmıyorum & 38 & 16,1 \\
\hline Kararsızım & 52 & 21,6 \\
\hline Katıllyorum & 62 & 26,3 \\
\hline Tamamen Katılıyorum & 72 & 30,1 \\
\hline Toplam & $\mathbf{2 3 6}$ & $\mathbf{1 0 0}$ \\
\hline
\end{tabular}

Katılımcıların \% 21,2'lik (50) kısmı gazetelerin haberin içinde zıt fikirlere yer vermediğine ya hiç katılmadığını ya da kısmen katılmadığını belirtmiştir. Bu konuda kararsız olduğunu belirtenlerin oranı ise \% 21,6'lık (52) kısmı oluşturmaktadır. Gazetelerin haberin içinde zıt fikirlere yer vermediğine katılanların oranı ise $\% 56,4$ (134) olmuştur.

Tablo 9. Gazeteler haberde farklı görüşlere yer vermemektedir (sınıflar)

\begin{tabular}{|l|c|c|}
\hline & 1. Sınıf & 4. Sinıf \\
\hline Hiç Katılmıyorum & $3(2,4)$ & $9(8,1)$ \\
\hline Kismen Katılmıyorum & $21(17,1)$ & $17(15,3)$ \\
\hline Kararsızım & $25(19,5)$ & $28(24,3)$ \\
\hline Katılıyorum & $29(23,6)$ & $33(29,7)$ \\
\hline Tamamen Katıliyorum & $46(37,4)$ & $25(22,5)$ \\
\hline Toplam (\%) & $\mathbf{1 2 3}(\mathbf{1 0 0})$ & $\mathbf{1 1 1}(\mathbf{1 0 0})$ \\
\hline
\end{tabular}

Araştırmaya katılan 1. Sınıf öğrencilerinin \% 19,5'i (24) gazetelerin haberin içinde zit fikirlere yer vermediğine katılmazken \%60,1'i (75) gazetelerin zıt fikirlere yer vermediğine katılmıştır. 4. Sınıf öğrencilerinin ise \% 23,4'ü gazetelerin haberin içinde zıt fikirlere yer vermediğine katılmazken, \% 52,2'si' (58) ise gazetelerin zit fikirlere yer vermediğine katılmıştır.

Tablo 10. Gazeteler verdikleri haberlerle kamuoyunu doğru bilgilendirmektedir

\begin{tabular}{|l|c|c|}
\hline & Öğrenci sayısı & Oran (\%) \\
\hline Hiç Katılmıyorum & 29 & 12,3 \\
\hline Kısmen Katılmıyorum & 65 & 27,5 \\
\hline Kararsızım & 59 & 24,6 \\
\hline Katılıyorum & 60 & 25,4 \\
\hline Tamamen Katıliyorum & 23 & 9,7 \\
\hline Toplam & $\mathbf{2 3 6}$ & $\mathbf{1 0 0}$ \\
\hline
\end{tabular}

Katılımcıların \% 39,8'i (94) gazetelerin verdikleri haberlerle kamuoyunu doğru bilgilendirdiğine hiç katılmadığını ya da kısmen katılmadığını belirtirken, katılımcıların \% 24,6'sı (59) kararsız olduğunu ifade etmiştir. Öğrencilerin yüzde 35,1'i (83) gazetelerin verdikleri haberlerle kamuoyunu doğru bilgilendirdiğine katıldığını ya da tamamen katıldığını ifade etmiştir.

Tablo 11. Gazeteler verdikleri haberlerle kamuoyunu doğru bilgilendirmektedir (sınıflar)

\begin{tabular}{|l|c|c|}
\hline & 1. Sinıf & 4. Sinıf \\
\hline Hiç Katılmıyorum & $8(6,5)$ & $21(18,8)$ \\
\hline Kısmen Katılmıyorum & $32(26)$ & $33(29,5)$ \\
\hline Kararsızım & $31(25,2)$ & $27(24,1)$ \\
\hline Katılıyorum & $37(29,3)$ & $25(21,4)$ \\
\hline Tamamen Katılıyorum & $16(13)$ & $7(6,2)$ \\
\hline Toplam (\%) & $\mathbf{1 2 4}(\mathbf{1 0 0})$ & $\mathbf{1 1 2 ( 1 0 0 )}$ \\
\hline
\end{tabular}

Copyright (C) 2015 by IJSSER

ISSN: 2149-5939 
İlhan, E., Çetintaş, A. (2015). A study of the reliability levels of the Faculty of Communication students on newspapers. International Journal of Social Sciences and Education Research, 1 (2), 560-571.

Soru birinci ve dördüncü sınıf öğrencilerinin verdiği cevaplar açısından incelendiğinde birinci sınıfların \% 32,5'i (40) dördüncü sınıfların ise \% 48,3’ü (54) gazetelerin verdikleri haberlerle kamuoyunu doğru bilgilendirdiğine katılmadığını ya da kısmen katılmadığını belirtmiştir. Gazetelerin verdikleri haberlerle kamuoyunu doğru bilgilendirdiğine katıldığını ya da tamamen katıldığını belirten birinci sınıfların oranı \% 42,3 (53) olurken, dördüncü sınıfların oranı ise \% 27,6 (32) oranında olmuştur.

Tablo 12. Gazetelerdeki haberlerin içeriğini yetersiz buluyorum

\begin{tabular}{|l|c|c|}
\hline & Öğrenci sayısı & Oran (\%) \\
\hline Hiç Katılmıorum & 53 & 22,5 \\
\hline Kısmen Katılmıyorum & 66 & 28 \\
\hline Kararsızım & 51 & 21,2 \\
\hline Katılıyorum & 39 & 16,5 \\
\hline Tamamen Katılıyorum & 27 & 11,4 \\
\hline Toplam & $\mathbf{2 3 6}$ & $\mathbf{1 0 0}$ \\
\hline
\end{tabular}

Katılımcıların \% 50,5'i (113) gazetelerdeki haberlerin içeriğinin yetersiz olduğuna hiç katılmadığını ya da kısmen katılmadığını belirtirken, öğrencilerin \% 21,2'si (51) kararsız olduğunu ifade etmiştir. Katılımcıların \% 27,9'u (63) gazetelerdeki haberlerin içeriğinin yetersiz olduğuna katıldığını ya da tamamen katıldığını ifade etmiştir.

Tablo 13. Gazetelerdeki haberlerin içeriğini yetersiz buluyorum (Sınıflar)

\begin{tabular}{|l|c|c|}
\hline & 1. Sınıf & 4. Sınıf \\
\hline Hiç Katılmıyorum & $31(25,2)$ & $22(19,6)$ \\
\hline Kısmen Katılmıyorum & $33(26,8)$ & $33(29,5)$ \\
\hline Kararsızım & $27(21,1)$ & $24(21,4)$ \\
\hline Katıliyorum & $20(16,3)$ & $19(17)$ \\
\hline Tamamen Katıllyorum & $13(10,6)$ & $14(12,5)$ \\
\hline Toplam (\%) & $\mathbf{1 2 4}(\mathbf{1 0 0})$ & $\mathbf{1 1 2 ( 1 0 0 )}$ \\
\hline
\end{tabular}

Soru birinci ve dördüncü sınıf öğrencilerinin verdiği cevaplar açısından incelendiğinde ise birinci sınıfların \% 52'si (64) dördüncü sınıfların ise \% 49,1'i (55) gazetelerdeki haberlerin içeriğinin yetersiz olduğuna katılmadığını ya da kısmen katılmadığını belirtmiştir. Gazetelerdeki haberlerin içeriğinin yetersiz olduğuna katıldığını ya da tamamen katıldığını belirten birinci sınıfların oranı \% 26,9 (33) olurken, dördüncü sınıfların oranı ise \% 29,5 (33) oranında olmuştur.

\section{Sonuç}

İletişim fakültesi öğrencilerinin gazetelere güven düzeylerinin incelendiği araştırmada, Ankara' daki iletişim fakültelerinde okuyan toplam 236 kişiye anket uygulanmıştır. İki bölüme ayrılan anket çalışmasının birinci bölümümde, katılımcılara daha çok demografik özellikleri ile ilgili sorular yöneltilirken, ikinci bölümde sorulan sorularda ise bu fakültelerde okuyan öğrencilerin gazetelere olan güven düzeyleri belirlenmeye çalışılmıştır.

Anket çalışması araştırmanın amacına uygun olarak iletişim fakültelerinde okuyan birinci ve dördüncü sınıf öğrencileriyle gerçekleştirilmiştir. Bu bağlamda ankete katılan toplam 236 öğrencinin \% 52,5'ini birinci sınıflar, \% 47,5'ini ise dördüncü sınıflar oluşturmaktadır. Gazi Üniversitesi, Ankara Üniversitesi ve Başkent Üniversitesi İletişim Fakültelerinde yapılan araştırmada katılımcıların \% 69,5'ini devlet üniversitelerinde okuyan öğrenciler, geriye kalan \% 30,5'lik kısmı ise özel üniversitede okuyan öğrenciler teşkil etmektedir. 
İlhan, E., Çetintaş, A. (2015). İletişim Fakültesi öğrencilerinin gazetelere güven düzeyleri üzerine bir araştırma. International Journal of Social Sciences and Education Research, 1 (2), 560-571.

Katılımcılar, "En fazla hangi tür haberleri takip ediyorsunuz" ifadesine \% 63,2 oranında politika-siyaset ve gündem haberlerini takip ettikleri cevabını vermiştir (Tablo 2). "Günlük haberleri en çok hangi iletişim kanalından alıyorsunuz" sorusuna ise katılımcıların yüzde 56,4'ü 'internet' yanıtını vermiştir(Tablo1). Çıkan sonuçlar iletişim fakültesi öğrencilerinin politika-siyaset ve gündeme dair haberleri daha çok internet üzerinden izlediklerini ortaya çıkarmıştır. Haberleri gazetelerden takip edenlerin oranı ise sadece \% 11 oranında kalmıştır.

Katılımcılar gündeme dair haberleri her ne kadar ağırlıklı olarak internet yoluyla takip ettiğini belirtse de, "Sizce hangi kitle iletişim aracı haber almada diğerlerine göre daha güvenlidir" sorusuna katılımcıların sadece \% 19,5'i interneti güvenilir bulduğu yönünde görüş belirtmiştir(Tablo 3). Bu durum göstermektedir ki, internet günümüzün en yaygın kitle iletişim aracı olmasına rağmen, güvenirlilik konusunda iletişim fakültesi öğrencilerini tatmin edememektedir. Bu bağlamda gazeteler iletişim fakültesi öğrencilerinin gözünde televizyondan sonra en güvenilir haber kaynağı olarak ortaya çıkmaktadır. Gazetelere olan güveni artıran bir diğer nokta ise gazetelerin doğruluğu kanıtlanmış bilgiler sunduğuna inanılması olmuştur. Bu çerçeveden bakıldığı zaman ise katılımcıların \% 42,3 gibi yüksek bir oranı bunu dile getirmiştir. Bu konuda kararsız olan kesim ise \% 24,2 oranındadır(Tablo4). Gazete haberciliğinin güvenilirliğine ilişkin birinci ve dördüncü sınıfların dağılımına bakıldığı zaman ise birinci sınıfların dördüncü sınıflara oranla gazetelere daha fazla güvendiği görülmektedir(Tablo5).

Üç üniversitenin iletişim fakültelerinde yapılan araştırma verilerinden elde edilen bir başka sonuç ise gazetelerde verilen haberlerin araştırmanın geneli açısından güvenilir bulunmadığıdır. Öğrencilerin yüzde 56,4'ü gazetelerin haberde farklı fikirlere yer vermediğini belirtirken(Tablo8), yüzde 39,8'lik kısmı ise gazetelerin verdikleri haberlerle kamuoyunu doğru bilgilendirmediğini ifade etmiştir(Tablo10).

Araştırma sonuçları göstermiştir ki; iletişim fakültesi öğrencilerinin büyük çoğunluğu gazetelerde verilen haberlere yeterince güvenmemektedir. Ankette yer alan soruların büyük bir bölümüne dördüncü sınıf öğrencilerinin birinci sınıf öğrencilerine oranla daha olumsuz cevaplar verdiği saptanmıştır. Bu durum, medya hakkında ayrıntılı bilgiye sahip oldukça öğrencilerin güven düzeylerinin azaldığını göstermektedir.

İletişim sektörüne üst düzey ve nitelikli eleman yetiştirmek amacıyla kurulmuş olan iletişim fakültelerinin öğrencileri, sektörün içinde bulunduğu mevcut durumdan hoşnut olmadıklarını, alanın güvenilirliğini kaybettiğini, geleneksel gazeteciliğin etkisinin azaldığını, mal ve hizmetlerin pazarlanmasının ön planda olduğu internet gazeteciliğinin ön plana çıktığını vurgulamışlardır.

\section{Kaynakça}

Çebi, M.S. (2002). Haberi Anlamak, Ankara: Gazi Kitabevi.

Erdoğan, İ., Korkmaz, A. (1990). İletişim ve Ankara:Toplum, Bilgi Yay.

Işik, M. (2002). Türkiye ve Dünya Bağlamında Kitle İletişim Sistemleri, Konya: Eğitim Kitabevi.

Oktay, M. (2002). Politikada Halkla İlişkiler, İstanbul: Derin Yayınları.

Özer, Ö. (2010). Liberal Basın, Konya: Literatür Yayınları.

Özer, Ö., Üçer, N.S. (2012). “Objektif Habercilik mi Yandaş Basın mı? Türkiye'de Yandaş Basın Örneği Olarak Sabah, Star, Yeni Şafak ve Zaman Gazetelerinin 29 Mart 2009 Genel Seçimlerinde Siyasal Partilere Yönelik Tutumu", Haberin Doğası, Özer Özer (Der), Konya, 2012, s: 119-145. 
İlhan, E., Çetintaş, A. (2015). A study of the reliability levels of the Faculty of Communication students on newspapers. International Journal of Social Sciences and Education Research, 1 (2), 560-571.

Poyraz, B. (2002). Haber ve Haber Programlarında İdeoloji ve Gerçeklik, Ankara: Ütopya Yayınevi.

Tiliç, L. D. (1998). Utanıyorum Ama Gazeteciyim, İstanbul: İletişim Yayınları.

İnternet Kaynakçası

http://www.akademycafe.com/web/index.php?option=com_jdownloads\&task=view.download\&cid=154\&Itemid=0 (Erişim, 14 Ocak 2012)

http://www.akademycafe.com/web/index.php?option=com_jdownloads\&task=view.download\&cid=154\&Itemid $=0($ Erişim, 14 Ocak 2012)

http://www.akademycafe.com/web/index.php?option=com_jdownloads\&task=view.download\&cid=154\&Itemid=0 (Erişim, 14 Ocak 2012) 
İlhan, E., Çetintaş, A. (2015). İletişim Fakültesi öğrencilerinin gazetelere güven düzeyleri üzerine bir araştırma. International Journal of Social Sciences and Education Research, 1 (2), 560-571.

\section{Extended abstract in English}

In this study titled "Confidence Levels of Faculty of Communication Students Regarding Newspapers", we have attempted to determine the attitude of Students of Communications in Ankara regarding the reliability of the news published in newspapers.

In Ankara, the population of the study were formed by first and fourth grade students of Communications at Gazi, Ankara and Baskent Universities. Subjects of the study were selected randomly from these group of students. Exploratory and descriptive survey method was used to reflect the views of the students in this study. A total of 236 subjects from the Faculty of Communications participated in this survey study. The survey was mainly separated to two sections, where questions related to the demographics of participants were present in the first section and questions related to the confidence level of the students regarding news published in papers were in the second section.

The survey was performed with the first and fourth grade students in line with the aims of this study. In this context, $52.5 \%$ of the 236 participants were first grade students, whereas $47.5 \%$ were fourth graders. The $69.5 \%$ of the participants were from state universities and 30,5\% were from private universities, all from Gazi, Ankara and Baskent Universities. 118 women and 118 men participated in the survey. Thus the proportion of men and women who responded to the survey was 50 and $50 \%$. Of the 236 participants, $9.7 \%$ of the students were under the age of $20,85,2 \%$ were between the ages 20 and $25,3.8 \%$ between 26 and 31 , while $1.3 \%$ were older than 32 .

Ninety participants ( $38.1 \%$ ) were from Gazi University, 74 (\% 31.4 ) from Ankara University and $72(30.5 \%)$ from Baskent University, all from City of Ankara. $37.7 \%$ (89) of subjects were Journalism students, $32.2 \%$ (76) were Public Relations and Publicity Department students, $24.6 \%$ (58) Department of Radio, Television and Film students. On the other hand, $124(52.5 \%)$ were 1 st year students and $112(47.5 \%)$ were $4^{\text {th }}$ year students.

When we look at the distribution across different universities, among the 124 first-year students, 48 (20.3\%) were from Ankara University, 39 (16.5\%) from Baskent University and 37 (15.7\%) from Gazi University. Fifty-three (22.5\%) participants were from Gazi University, 33 (14\%) from Baskent University and 26 (11\%) from Ankara University. In response to the question "What kind of news do you follow the most?" $63.2 \%$ gave the answer that they follow news regarding politics and daily agenda. In response to the question "Which communication medium do you use the most?", 56.4 percent responded as 'Internet'. These results revealed that policy and politics and communication school students follow the news more on the internet. The percentage of those who follow the news from newspapers remained only at $11 \%$.

Although participants mainly followed news through the Internet, only $19.5 \%$ of respondents finds internet reliable according to their responses to the question "Which news source is more reliable than others in receiving news". This suggests that, although the Internet is participants' mostly used medium, it is unable able to satisfy Communications students in terms of reliability. In this context, newspapers are emerging as the second most reliable source of news following television according to students. Another point that increases confidence in the accuracy of the newspapers is that news provided in the newspapers are believed to be confirmed. From this perspective, a high percentage of $42.3 \%$ of respondents expressed this opinion. Another 
İlhan, E., Çetintaş, A. (2015). A study of the reliability levels of the Faculty of Communication students on newspapers. International Journal of Social Sciences and Education Research, 1 (2), 560-571.

$24.2 \%$ who are impartial on this issue. When we look at the distribution of the reliability of newspapers among first and fourth grades, it seems that first grade students have more confidence in newspapers compared to fourth class students.

Another result obtained from the research carried out in three universities is that majority of the participants do not find newspapers reliable. 56.4 percent of students stated that newspapers do not publish opposing/alternative opinions, while 39.8 percent said that incorrect information is provided on newspaper reports.

Research results show that; majority of communications students do not sufficiently trust majority of newspapers. When we look at the he majority of questions in the questionnaire seniors were found to give more negative responses compared to freshmen students. This shows that students' confidence levels have decreased as they acquire more information about the media. Students of the Communications Faculty established to train qualified and high level staff, are found to be unhappy with the current situation of the sector, to think that the field has lost its credibility, that the influence of traditional journalism is decreasing, and finally that internet journalism where marketing of goods and services have priority is becoming more important.

In light of the data obtained from the survey we have found that students do not find news in the newspapers reliable. Also, fourth grade students are found to respond more negatively in general compared to the first year students based on the data obtained. 